\title{
Verleden, heden en toekomst van de oogheelkunde
}

Citation for published version (APA):

Lamers, W. P. M. A. (1992). Verleden, heden en toekomst van de oogheelkunde. Maastricht University. https://doi.org/10.26481/spe.19920101wl

Document status and date:

Published: 01/01/1992

DOI:

10.26481/spe.19920101wl

Document Version:

Publisher's PDF, also known as Version of record

\section{Please check the document version of this publication:}

- A submitted manuscript is the version of the article upon submission and before peer-review. There can be important differences between the submitted version and the official published version of record.

People interested in the research are advised to contact the author for the final version of the publication, or visit the DOI to the publisher's website.

- The final author version and the galley proof are versions of the publication after peer review.

- The final published version features the final layout of the paper including the volume, issue and page numbers.

Link to publication

\footnotetext{
General rights rights.

- You may freely distribute the URL identifying the publication in the public portal. please follow below link for the End User Agreement:

www.umlib.nl/taverne-license

Take down policy

If you believe that this document breaches copyright please contact us at:

repository@maastrichtuniversity.nl

providing details and we will investigate your claim.
}

Copyright and moral rights for the publications made accessible in the public portal are retained by the authors and/or other copyright owners and it is a condition of accessing publications that users recognise and abide by the legal requirements associated with these

- Users may download and print one copy of any publication from the public portal for the purpose of private study or research.

- You may not further distribute the material or use it for any profit-making activity or commercial gain

If the publication is distributed under the terms of Article $25 \mathrm{fa}$ of the Dutch Copyright Act, indicated by the "Taverne" license above, 
Universiteitsbibliotheek

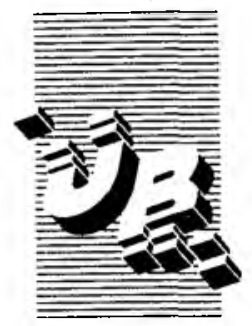

De vitleentermijn verstrijkt op:

\section{SEP. 1995}

Rijksuniversiteit Limburg

Postbus 616

6200 MD Maastricht

Gelieve deze publicatie tijdig te retourneren of (telefonisch) verlenging van de uitleentermijn aan te vragen.

\section{UNIVERSITEITSBIBLIOTHEEK RU LIMBURG

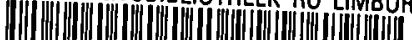


Verleden, Heden en Toekomst VAN DE

OOGHEELKUNDE 


\title{
Verleden, Heden en Toekomst VAN DE \\ OOGHEELKUNDE
}

\author{
W.P.M.A. Lamers
}

\author{
afscheidsrede uitgesproken \\ ter gelegenheid van bet emeritaat \\ van \\ Prof. dr. W.P.M.A. Lamers \\ Hoogleraar Oogbeelkunde \\ aan de \\ Rijksuniversiteit Limburg
}




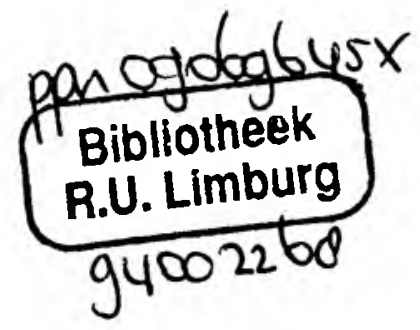




\section{Dames en Heren}

Het is altijd moeilijk een goed onderwerp te vinden voor een afscheidscollege. De toehoorders bij zo'n gebeurtenis hebben vaak een verschillende achtergrond. Een verhaal, waarbij diep wordt ingegaan op typisch oogheelkundige problemen, zou de oogartsen onder de aanwezigen misschien wel boeien, maar de anderen, oogheelkundig niet geschoold, zouden al snel het spoor bijster zijn. Ik zal trachten me hieraan niet te bezondigen. Het is natuurlijk duidelijk, dat ik zal praten over zaken, die de oogheelkunde betreffen. Alleen zal ik proberen het zodanig gestalte te geven, dat iedereen kan worden geboeid zowel vakgenoten, als buitenstaanders. Een afscheidscollege is vaak een terugblik op het verleden zonder veel oog voor de toekomst. Men zal dan, terugblikkend op het afgesloten tijdperk, een balans opmaken en eventueel met meer of mindere voldoening terugzien op het in het verleden gepresteerde. Een betoog, waarbij de nadruk ligt op de toekomstplannen, hoort meer thuis in een inaugurale rede. Hierin worden de toekomstplannen ontvouwd van de nieuwbenoemde hoogleraar. Ik behoor echter tot die hoogleraren, die tot de eerste generatie van deze universiteit moeten worden gerekend. De universiteit werd gesticht in 1973. In 1974 werd een begin gemaakt met de studie Geneeskunde en de eerste studenten arriveerden in Maastricht. Er bestond nog een zeer jeugdig enthousiasme. Er waren veel idealen, alles moest anders en niets mocht herinneren aan 
de traditionele universiteiten. Toga's waren uit den boze en inaugurale rede's werden niet gehouden of liever mochten niet worden gehouden. Gelukkig is daar in de loop der jaren verandering in gekomen. Men heeft ingezien, dat niet alle oude waarden zinloos zijn. Langzaam wordt een balans gevonden tussen het nieuwe en het weer mondjesmaat terugkerende oude, zodat er een werkelijke en zinvolle vernieuwing kan optreden met het behoud van waardevolle verworvenheden uit het verleden. Ook in Maastricht worden weer netjes oude vertrouwde rituelen van de Alma Mater gekoesterd. Iedere nieuw benoemde hoogleraar houdt weer zijn inaugurale rede en wel in toga. En wat voor een toga, Maastricht waardig, niet het sombere calvinistische zwart, maar het kleurrijke, bourgondische rood. De Maastrichtse hoogleraren zijn in vreemde cortège's heel duidelijk herkenbaar. Ze springen er uit, in ieder geval wat betreft hun uiterlijk. Het feit, dat ik nog behoor tot de generatie, die geen rede heeft gehouden bij het aanvaarden van het ambt, geeft mij nu een rechtvaardiging om aan het einde van mijn loopbaan een inaugurale rede en een afscheidscollege te combineren en te proberen dit tot een geheel te maken, waarbij zowel mijn kijk op het verleden als mijn gedachten over de toekomst aan bod zullen komen. Ik zal proberen $U$ mijn visie te geven op de ontwikkeling van de oogheelkunde en $U$ deelgenoot maken van mijn zorgen voor de toekomst, maar nog meer van mijn vertrouwen in de komende generatie oogartsen. Ik hoop hiermee onder de beroepsgenoten begrip te wekken voor mijn ideeën betreffende de toekomst. In ieder geval moet duidelijk zijn dat heel mijn betoog wordt ingegeven door mijn liefde voor de oogheelkunde. De anderen, niet vakgenoten, hoop ik duidelijk te maken, dat oogheelkunde een bijzonder mooi specialisme is en dat de oogheelkunde een zeer belangrijke plaats inneemt in de geneeskunde. Het eerste deel zal zich beperken tot het verleden. De ontwikkeling in de oogheelkunde zal hier worden belicht. Het laatste deel zal bestaan uit mijn visie op de oogheelkundige toekomst. 
We leven op het ogenblik in een bijzonder dynamische tijd. De twintigste-eeuw is een tijd, waarin niet alleen technische ontwikkelingen elkaar in razend snel tempo opvolgen, maar ook geestelijke waarden blijken aan grote veranderingen onderhevig te zijn. Bij de overgang naar de een en twintigste-eeuw lijken nog ongekende mogelijkheden op ons af te komen. Aardse afstanden bestaan niet meer. Het lijkt niet meer ver weg te zijn of ook de buitenaardse ruimte zal echt worden veroverd en ontdekt. De eerste schreden zijn door de mensheid al gezet bij de exploratie van het heelal. Vreemde culturen zijn binnen ieders bereik. Oude waarden blijken niet meer de eeuwigheidswaarde te hebben, die ze altijd is toegeschreven. In 10 jaar tijd gebeurt tegenwoordig meer en hebben grotere ontwikkelingen plaats dan vroeger in honderden jaren. Het is bijzonder boeiend in een dergelijk tijdsgewricht te leven. Het vergt echter een grote mate van flexibiliteit en een openstaande geest. Men moet bereid zijn echt te luisteren en de moed opbrengen nieuwe wegen in te slaan. Natuurlijk zijn niet alle veranderingen verbeteringen, maar ook alle oude waarden zijn niet per definitie goed. Het is zaak om al zoekend met elkaar een wereld te creëren aangepast aan deze tijd en bereid tot verandering. Maar laten we terug keren tot ons eigenlijke onderwerp de oogheelkunde. De oogheelkunde maakt geen uitzondering op dit algemene tijdsbeeld. Ook hier vinden in de laatste decennia veranderingen plaats in een zeer snel tempo. Veranderingen en ontwikkelingen, die vroeger generatie's nodig hadden om zich te ontplooien en algemeen goed te worden, vinden nu plaats binnen één mensenleven. Het vergt dan van de oogartsen een hoge mate van alertheid en een zeer intensieve nascholingsactiviteit. Men kan niet meer teren op de kennis en vaardigheden opgedaan tijdens de opleiding. De veranderingen vinden in een zo snel tempo plaats, dat men binnen 10 jaar hopeloos achter zou lopen, wanneer men niet actief de ontwikkelingen zou volgen. Als illustratie voor de dynamiek in de huidige tijd kan de geschiedenis van de cataractextractie als voorbeeld dienen. 
De behandeling van de staar is al van zeer oude datum. Ver voor onze jaartelling kende men al methoden om de mensen van de staar te genezen. Ook al was men niet op de hoogte van de ware toedracht. De officiële term voor grijze staar is cataract. Dit komt van het griekse woord cataracta, wat waterval betekent. Bij de staar treedt er een witte verkleuring op van de pupil. Men dacht vroeger, dat er vocht in de pupilopening naar beneden stroomde en daar stolde tot een witte massa. De gelijkenis met een waterval, het witschuimende naar beneden vallende water, heeft geleid tot de benaming cataract. Naar alle waarschijnlijkheid is de eerste chirurgische behandeling van de staar in India gepraktiseerd. De Sucruta, de neergeschreven overlevering van de oude Brahmanen, hindoe priesters, van ver voor onze jaartelling, maakt melding van twee chirurgische ingrepen; de neusreconstructie en de staarsteek. U zult zich misschien verbazen, waarom uitgerekend de neusreconstructie tot de chirurgische ingrepen hoort, die worden beschreven. Welnu het was in het oude India de gewoonte lijfstraffen toe te passen. Bij een overspelige vrouw werd de neus afgesneden. Een overspelige man komt helaas in de tekst niet voor, wat waarschijnlijk meer zegt over de mannelijke samenstellers van de wetgeving dan over het gedrag van de man in die tijd. Om na verloop van tijd deze verminking weer op te heffen werd een neusreconstructie beschreven met een gesteelde huidlap. Ook de staarsteek werd in de Sucruta vermeld. Men maakte met een scherp mesje een opening in de sclera (de harde oogrok) en vervolgens stak men door deze opening een stompe naald, waarmee de staar uit de pupilopening werd weggedrukt. Tot 1700 was een behandeling van de staar alleen mogelijk via een staarsteek. Gedurende ongeveer 2000 jaar veranderde er weinig aan de behandeling. In de middeleeuwen werd de staarsteek eigenlijk voornamelijk uitgevoerd door de staarstekers. Dit waren geen medici, maar kwakzalvers, die de jaarmarkten afreisden en daar tot vermaak van de omstanders de staarsteek toepasten. De staarsteek was dus eigenlijk een poliklinische ingreep. Na de neerdrukking kon de patiënt weer direct naar huis gaan. De staarsteker 
verdween na de jaarmarkt weer naar de volgende plaats. Voor de mislukkingen, die natuurlijk vaak voorkwamen, konden ze dan ook niet meer ter verantwoording worden geroepen. In de $17 \mathrm{de}$ eeuw begonnen de medici zich ook weer met de staarsteek bezig te houden. Helaas namen ze veel slechte gewoonten over van de kwakzalvers. In de 18de-eeuw trad een ommezwaai op in de behandeling van de staar. Het was 1745 toen Jaques Daviel de eerste cataractextractie verrichtte. Het was een extra-capsulaire cataractextractie, d.w.z. de lenskapsel werd geopend en de troebele lensinhoud werd verwijderd. Honderd jaar later echter was de staarsteek nog steeds volop in zwang. In de "Iconographie Ophthalmologique" van J. Sichel uit 1852 lezen we "Les méthodes fondamentales d'opérer la cataracte sont au nombre de trois, l'ex. traction, l'abaissement et le broiement'. Pas in de tweede helft van de 19de eeuw was iedereen overtuigd van de voordelen van de cataractextractie tegenover de staarsteek. In het begin van deze eeuw werd de intracapsulaire cataractextractie ingevoerd. Hierbij werd de lens verwijderd samen met het kapsel. Het grote voordeel van deze ingreep was, dat er geen nastaar meer kon ontstaan. In de vijftiger jaren werd een nieuwe mijlpaal bereikt met de ontwikkeling van de intra-oculaire lens, waarbij onze landgenoot dr. C. Binkhorst een grote rol heeft gespeeld. Op deze manier kon er een praktisch fysiologische situatie worden gecreëerd. Het herstel van de gezichtsscherpte kan met deze methode $100 \%$ bedragen en de situatie is eigenlijk te vergelijken met een normaal functionerend oog. Het is verwonderlijk hoe toevalligheden vaak bijdragen tot omwentelingen in aanpak en techniek. Ook dat is goed te illustreren aan de hand van de geschiedenis van de cataractextractie. Hoe Jaques Daviel er toe is gekomen de extra-capsulaire cataractextractie te propageren en in te voeren.

Jacques Daviel, geboren in La Barre, een dorpje vlak bij Rouen, op 11 Augustus 1696, was de zoon van de dorpsnotaris. Aanvankelijk was hij werkzaam als chirurgijn, maar sinds 1728 hield hij zich nog maar alleen bezig met de oogheelkunde. Op 8 April 1745 opereerde hij de kluizenaar van Aiguilles. De- 
ze kluizenaar was reeds aan één oog geopereerd door een ander, zonder succes. Hij consulteerde nu Jacques Daviel en vroeg hem het andere oog te behandelen. De operatie, die Daviel uitvoerde, was de gebruikelijke neerdrukking van de staar. Hij was echter niet gelukkiger dan zijn voorganger. De staar verbrokkelde en kwam in de voorste oogkamer, bovendien trad er een bloeding op. Op dat moment herinnerde Daviel zich een publicatie van iemand, die het oog had geopend. Hij nam een lans, opende het hoornvlies aan de benedenzijde, zodat het bloed en de verbrokkelde lens konden wegvloeien. De pupil werd helder en de patiënt kon direct postoperatief weer voorwerpen onderscheiden. Helaas trad na enige dagen een infectie op, zodat het uiteindelijke resultaat niet erg bevredigend was. Toch was hij van mening, dat deze methode de voorkeur verdiende boven de staarsteek. En hij ging op de ingeslagen weg verder. Find 1756 had Daviel 434 staaroperatie's verricht, waarvan er slechts 50 waren mislukt. Op 13 April 1752 hield Jacques Daviel een voordracht voor de Académie in $\mathrm{Pa}$ rijs over zijn nieuwe techniek om de staar te genezen door middel van verwijdering van de lens. Dit is het begin geweest van de cataractextractie, een ingreep, die nog steeds volgens dezelfde principe's wordt gepraktiseerd. Ook aan de invoering van de intraoculaire lensimplant hebben toevallige gebeurtenissen ten grondslag gelegen. Tijdens de tweede wereldoorlog zag men, vooral bij de slag om Engeland, veel Spitfire piloten met verwondingen veroorzaakt door splinters van hun persplex cockpit. Het bleek, dat deze stukjes persplex in het oog terecht gekomen volledig inert waren. Daarop is door Harold Ridley in 1949 in het Thomas Hospital in Londen de eerste intra-oculaire lens geimplanteerd van persplex materiaal. Sindsdien zijn de ontwikkelingen elkaar in snel tempo opgevolgd. Er zijn inmiddels de meest uiteenlopende intraoculaire lenzen ontwikkeld. Lenzen, die in de voorste oogkamer worden geplaatst en achterkamerlenzen. Deze laatste, die in de kapselzak worden geplaatst, worden momenteel zeker in Nederland het meeste gebruikt. De ontwikkeling van de microchirurgische technieken, die een betere manipulatie waarborgen, waar- 
door de ingreep minder traumatiserend is. De phaco-emulsificatie, die het mogelijk maakt door een uiterst kleine opening te opereren. Een zodanig weinig traumatiserende ingreep, dat de patiënt van de operatietafel direct kan opstaan en naar huis gaan, de poliklinische cataractextractie. Het is onvoorstelbaar te zien hoe in één mensenleven zo'n enorme veranderingen kunnen plaatsvinden. Ik kan me nog herinneren, dat in mijn opleidingstijd patiënten, die aan staar moesten worden geopereerd, 10 dagen in het ziekenhuis werden opgenomen. De eerste dagen postoperatief was bewegen absoluut niet toegestaan en ze werden zelfs in bed geopereerd om te voorkomen, dat tijdens het overtillen of overstappen van operatietafel naar bed problemen zouden ontstaan. Je had voor deze patiënten aparte bedden, waarvan het hoofdeinde kon worden verwijderd. Ook de ontwikkelingen in de materialen wekken grote verwachtingen. De multifocale intra-oculaire lenzen zijn nu al in gebruik ook al is het nog op beperkte schaal en de accommoderende lenzen zijn in ontwikkeling.

De enorme ontwikkelingen zijn vooral een gevolg van de grote technische vooruitgang in de laatste jaren. De informatica heeft een zeer grote invloed op de moderne geneeskunde en dus ook op de moderne oogheelkunde. Als voorbeeld kan hier worden aangehaald de ontwikkelingen in de perimetrie. In mijn opleidingstijd moesten wij als assistent de gezichtsvelden maken bij de glaucoom controle. De perimeter bestond uit een zwarte doek, die aan de muur hing, waarop het gezichtsveld was geborduurd met wit garen. Met zwarte stokjes, waarop witte of gekleurde rondjes waren geplakt, moest het gezichtsveld worden afgezocht naar defecten. U kunt zich voorstellen, dat de betrouwbaarheid van deze onderzoekmethodiek maar zeer twijfelachtig was. Al snel kwam de Goldmann perimeter, die een geweldige vooruitgang betekende op het gebied van de reproduceerbaarheid en de nauwkeurigheid bij het maken van gezichtsvelden. Momenteel zijn automatische perimeters te koop, die aangesloten aan een personal computer, tot de meest ingewikkelde bewerkingen in staat zijn. Gezichtsvelden kunnen electronisch worden opgeslagen 
en op elk moment weer opnieuw worden opgeroepen. Alle gegevens kunnen dan op verschillende manieren worden bewerkt en vergeleken.

Ook de ontwikkeling van de lasertechnologie is een geweldige verbetering geweest in de behandeling van diverse retinale afwijkingen, met name de diabetische retinopathie. Ook op dit terrein staan de ontwikkelingen niet stil. Steeds weer nieuwe lasertypen worden op de markt gebracht met nieuwe en soms onverwachte toepassingsmogelijkheden. Een van de nieuwste typen is de Excimer laser. Hiermee kan het hoornvlies worden gepolijst, zodat refractie afwijkingen kunnen worden opgeheven. Op deze manier kan mogelijk in de toekomst het gebruik van brillen worden beperkt, zeker in het geval van ernstige refractie afwijkingen zou dat een uitkomst zijn.

Tenslotte zou ik nog willen noemen de vitreoretinale chirurgie. Deze ontwikkeling, waarbij het mogelijk is geworden het glasvocht te attaqueren en met het netvlies te manipuleren, is een van de meest spectaculaire van de laatste decennia. Het netvlies en ook het glasvocht is in de oogheelkunde altijd beschouwd als het heilige der heiligen. Dankzij zeer verfijnde microchirurgische technieken kan momenteel het netvlies worden gezuiverd van ongerechtigheden, zowel aan de voorzijde als aan de achterzijde. Ook op dit gebied neemt de Nederlandse oogheelkunde een voorname plaats in. Collega Zivojnovic is een van de toonaangevende vitreo-retinale chirurgen, die baanbrekend werk op dit gebied hebben verricht. Het is vooral het zeer verfijnde instrumentarium, de optische mogelijkheden en het gebruik van silicone-olie als vervanger van het glasvocht, die tot deze ontwikkeling hebben bijgedragen.

Mijn opsomming van de ontwikkelingen in de oogheelkunde is lang niet volledig. Het is niet meer dan een zeer kleine bloemlezing uit de mogelijkheden, die er momenteel zijn. Ik hoop $U$ echter een indruk te hebben gegeven van de enorme veranderingen, die zich de laatste jaren hebben voltrokken. Ik prijs me gelukkig deze vooruitgang van dichtbij te hebben mogen 
meemaken. De ontwikkelingen spelen zich in een steeds sneller tempo af en ik heb het idee, dat we op de drempel staan van nog grotere verbeteringen.

In het voorgaande hebben we uitvoerig stilgestaan bij de veranderingen, die zich hebben voorgedaan bij de diagnostiek en behandeling van oogaandoeningen. Het is vanzelfsprekend, dat men onder de indruk komt van de mogelijkheden, die er dit moment bestaan en van alle ingrepen, die aan het oog kunnen worden uitgevoerd. Hierdoor is echter het gevaar aanwezig en misschien wel groot, dat er door al deze technische ontwikkelingen alleen nog maar oog is voor de techniek. De mogelijkheden het oog te behandelen zijn enorm uitgebreid. De techniek viert zo'n hoogtij, dat we moeten oppassen, dat de mens niet op de achtergrond raakt. $\mathrm{Bij}$ al onze technische verworvenheden moeten we nooit uit het oog verliezen, dat we te maken hebben met patiënten. Met mensen, die de hulp van de oogarts inroepen bij visuele klachten. Soms zijn de klachten heel duidelijk gerelateerd aan het oog, soms zijn het zeer vage klachten en zijn de visuele klachten een uiting van een andere problematiek. Ook de oogarts moet met een begrijpend oor luisteren naar zijn patiënt. Een van de zaken, die in Maastricht vanaf het begin veel aandacht heeft gekregen, is de behandeling van de totale patiënt. Met gebruikmaking van al de technische verworvenheden laten we ons toch vooral leiden door de patiënt in zijn totaliteit. Men zal zich steeds moeten afvragen of een bepaalde ingreep bij deze bepaalde patiënt wel bijdraagt tot zijn welbevinden. Het is niet de technische haalbaarheid van een ingreep of behandeling, die doorslaggevend is voor de beslissing om een ingreep te verrichten. Maar men zal soms ook het onmogelijke moeten proberen anders kan er niet grensverleggend gewerkt worden, maar dit mag alleen met veel prudentie gebeuren. Vooral in een opleidingssituatie moet men aan deze aspecten grote aandacht besteden. Ik kan $U$ verzekeren, dat wij in Maastricht ons uiterste best doen om de toekomstige oogartsen de juiste instelling mee te geven, om ze niet tot orgaanspecialisten te maken, maar hen te doordringen van het feit, dat steeds een 
patiënt in zijn totaliteit wordt behandeld.

Oogheelkunde is altijd een wat solitair opererend vak geweest. In de zestiger jaren echter heeft de oogheelkunde een steeds grotere plaats gekregen in de algemene ziekenhuizen. Het werd in het verleden gerekend tot de zogenaamde kleine specialismen. Dankzij de technische ontwikkelingen heeft het vak zich duidelijker geprofileerd en wordt momenteel als een volwaardig en belangrijk specialisme erkend en terecht. Door de vergrijzing van de bevolking zullen steeds meer mensen oogheelkundige zorg behoeven. Het zijn in de oogheelkunde vooral de oudere patiënten, die om hulp vragen. De cataract en de maculadegeneratie zijn typische aandoeningen van de oudere leeftijd. Ook het glaucoom is een aandoening, die op oudere leeftijd meer voorkomt. Vooral de staar is een aandoening, die met veel succes kan worden behandeld, dankzij de huidige technieken en de gebruikte materialen voor implantlenzen. Er is een onderzoek geweest naar het effect van verschillende operatie's op de kwaliteit van het leven, zoals de by-pass operatie, de total hip en de cataractextractie. En het blijkt heel duidelijk, dat de total hip en de cataractextractie op de eerste plaats staan, terwijl de coronary by-pass operatie, waarvan men zou verwachten dat deze bovenaan zou staan, slechts onderaan is aan te treffen. Een situatie, die men zo op het eerste oog niet zou verwachten. Dat oogheelkunde zijn plaats in het ziekenhuisbestel wel degelijk heeft veroverd moge blijken uit de poliklinische activiteit van een oogheelkundige polikliniek binnen het ziekenhuis. Als we de cijfers bekijken van het aantal polikliniekbezoeken, dan blijkt, dat de polikliniek oogheelkunde tot de grootste behoort van het ziekenhuis en dan te bedenken, dat deze work load moet worden verricht met een minimum aan mankracht. Het is dan ook niet verwonderlijk, dat door deze enorme werkdruk op de polikliniek enorme wachttijden zijn ontstaan. Het aantal mensen, wat oogheelkundige zorg vraagt, wordt steeds groter en het antal oogartsen neemt nauwelijks toe.

Het is wel duidelijk, dat de inhoud van de oogheelkunde in de loop van de laatste jaren aanzienlijk is gewij- 
zigd. Het grootste deel van deze verandering is toe te schrijven aan de geweldige technische vooruitgang. Het aanzien van ons vak heeft hierdoor een forse opwaardering ondergaan en terecht. Door de vergrijzing van de bevolking zal het beroep, wat wordt gedaan op de oogheelkundige voorzieningen, enorm toenemen. In het licht van deze veranderingen is het zeker zinvol een balans op te maken van de huidige stand van zaken in de oogheelkunde en een weg uit te stippelen voor de toekomst. De oogheelkundige wereld heeft dat zeer goed onderkent en heeft een plan opgesteld, wat richting moet geven aan de toekomstige oogheelkundige zorg in Nederland.

Kijken we goed om ons heen dan zien we de hele geneeskunde en ook de oogheelkunde of misschien zelfs expliciet de oogheelkunde steeds commerciëler worden. De combinatie oogheelkundige praktijk-opticiënswinkel behoort niet meer tot de uitzonderingen. Het is niet meer altijd duidelijk of de oogarts een geneesheer is, die met het lot van zijn patiënten is begaan of een gewiekst zakenman, die een goede balans weet te creëren. Begrijp me goed, ik heb niets tegen zakenlieden, maar ik heb wel iets tegen de combinatie van beiden. Ik denk, dat dit een combinatie is, die een van beide kwaliteiten te kort doet. Het is best begrijpelijk, waarom deze tendens zich heeft doorgezet. Door de steeds grotere beperkingen en regelgevingen, die de mensen vooral aantasten in hun financiële mogelijkheden, zodanig zelfs, dat sommigen onder het bestaansminimum terecht komen, wordt men gedwongen alternatieve uitkomsten te zoeken. Toch geeft ons dat geen vrijbrief om op deze manier te handelen. We moeten hier paal en perk aan stellen en er voor zorgen, dat deze commerciële activiteiten niet meer nodig zijn. Het moet mogelijk zijn om een behoorlijk bestaan op te bouwen met alleen oogheelkundige werkzaamheden.

Op wat voor manier nu is het mogelijk een goed uitgebalanceerde oogheelkundige zorg te creëren, waarbij de hoge kwaliteit behouden blijft en waarbij de werkvreugde volop aanwezig is zonder dat men hoeft te vechten voor een maat- 
schappelijk acceptabele leefwijze. Ik wil $U$ trachten te schilderen hoe mijn ideaalbeeld van een oogheelkundige gezondheidszorg is en ik ben er van overtuigd, dat velen en met name de jongeren in veel opzichten mijn inzichten zullen delen.

Dat er een probleem bestaat bij de oogheelkundige zorg is voor iedereen duidelijk. De vraag naar oogheelkundige hulp neemt toe en het aantal oogartsen is de laatste jaren nauwelijks gestegen. Hierdoor zijn de wachttijden voor oogheelkundige hulp sterk toegenomen en nemen nog steeds toe. Om dit probleem te kunnen oplossen zijn verschillende oplossingen te bedenken. In de eerste plaats maatregelen op korte termijn, die snel iets kunnen veranderen aan het wachttijden probleem. Belangrijker zijn volgens mij maatregelen, die op langere termijn structurele veranderingen aanbrengen om een blijvende verbetering van de situatie te krijgen.

Het is zaak om te komen tot een goede oogheelkundige zorg, waarbij de patiënt een optimale behandeling krijgt en de behandelaar plezier in zijn werk heeft en houdt. Hoe is de gezondheidszorg in Nederland georganiseerd? We kennen de eerstelijns gezondheidszorg en de tweedelijns gezondheidszorg. Het is bij ons zo, dat de eerstelijns gezondheidszorg en met name de huisartsgeneeskunde de laatste jaren een sterke opwaardering heeft gekregen. De huisarts is in deze opvatting diegene, die het dichtste bij de patiënt staat en bij de behandeling en begeleiding van zijn patiënten een centrale plaats inneemt. De huisarts zal het eerste aanspreekpunt moeten zijn voor zijn patiënten. En in overleg met de patiënt zal verwijzing naar de tweede lijn, de specialistische gezondheidszorg moeten plaats vinden. Op deze manier kunnen onnodige specialistische behandelingen worden voorkomen. Dit geeft niet alleen een betere verdeling van de inspanningen, maar zal de specialist ook meer specifieke op zijn terrein relevante handelingen laten verrichten. Een voorwaarde voor een dergelijk opereren van de huisartsen is een adequate opleiding. Het oude artsexamen is inmiddels veranderd in een basisartsexamen. $\mathrm{Na}$ het behalen van dit basisartsexamen zal men om als huisarts te kunnen 
functioneren een vervolg opleiding moeten volgen. De oogheelkundige kennis, die een basisarts bezit, verkregen tijdens een coassistentschap van drie weken, is absoluut onvoldoende. Tijdens deze drie weken kan men alleen maar kennis maken met het specialisme, meer niet. De eigenlijke oogheelkundige opleiding zal moeten geschieden tijdens de huisartsen-opleiding en wel gedurende een half jaar, waarin de theoretische kennis kan worden verworven en de vaardigheden kunnen worden geoefend in de praktijk binnen de huisartsen-opleiding. Zeker nu de huisartsenopleiding 2 jaar bedraagt en in de nabije toekomst zelfs zal worden verlengd tot 3 jaar. Deze opleiding kan alleen zinvol worden verzorgd door een huisarts met speciale belangstelling voor de oogheelkunde en een specialist, die als inhoudsdeskundige het leerproces kan en moet bewaken. Ik denk overigens, dat deze formule niet alleen geldt voor de oogheelkunde, maar voor alle andere deelgebieden ook.

Wat zal de voornaamste taak van de huisarts zijn in de eerstelijns oogheelkundige zorg? Naar mijn mening is dat het onderscheid maken tussen pluis en niet pluis. Op deze manier zal een deel van de patiënten, die nu het specialistische oogheelkundige circuit frequenteren, naar andere kanalen worden verwezen. Het aanbod aan pathologie voor de oogarts zal hierdoor toenemen. Bovendien zouden door de huisarts relatief eenvoudige ingrepen kunnen worden verricht, waardoor de oogarts verder zou kunnen worden ontlast. Op deze manier zal ieder op zijn terrein nog meer plezier in zijn werk krijgen dan nu al het geval is.

Ook de opticiën zal in deze constructie de plaats krijgen, die hem toekomt. Een groot deel van de refractie kan bij patiënten, die het huisartsen station zijn gepasseerd en waar het predicaat pluis is afgegeven, worden verricht door de opticiën. Een absoluut onwenselijke situatie is de toestand, waarbij de huisarts de patiënt naar de opticiën verwijst zonder hem te hebben onderzocht. En de opticiën op zijn beurt de cliënt doorverwijst naar de oogarts, nadat hij hem wel heeft onderzocht, 
De medische zaken moeten binnen het medische circuit blijven. De ideale oplossing zal dus zijn een versterking van de oogheelkundige zorg in de eerste lijn te bewerkstelligen door een betere oogheelkundige opleiding van de huisartsen, dit uitgevoerd in nauwe samenwerking tussen huisartsgeneeskunde en oogheelkunde.

Wel wil ik nog even ter sprake brengen de vaardigheden, die de huisarts zich eigen zal moeten maken en het instrumentarium dat hiervoor nodig is. Ik denk dat de huisarts het basale oogheelkundig instrumentarium tot zijn beschikking moet hebben om op verantwoorde wijze de pluis niet pluis strategie te kunnen hanteren. Tot dit instrumentarium reken ik de letterkaart, de oogspiegel en de spleetlamp. Ik hoor nu oogartsen al protesteren. De spleetlamp is jarenlang het onderzoeksinstrument van de oogarts geweest en nu zou dat plotseling tot het domein van de huisarts gaan horen. Het is haast heiligschennis. Toch geloof ik niet dat deze opstelling juist is. De diagnostiek op oogheelkundig gebied heeft zich in de loop der jaren sterk ontwikkeld. De opsporing van ziekten is naar een steeds vroeger tijdstip verschoven. Het is ondenkbaar, dat momenteel een oogarts zijn patiënten met focale belichting, met een lampje en een loupe, onderzoekt. Toch heb ik de tijd nog meegemaakt, dat oudere oogartsen deze methodiek hanteerden. Tegenwoordig is dat niet meer voor te stellen. Langzaam is het nu echter ook tijd, dat deze onderzoekmethoden ook ingang vinden in de huisartsenpraktijk. Waarom zouden wij bang moeten zijn om de huisarts het gebruik van een eenvoudige speetlamp aan te leren? Ik ben er van overtuigd, dat door deze ontwikkeling de oogheelkundige patientën op een vroeger tijdstip naar de oogarts worden verwezen, wat een betere en effectievere behandeling tot gevolg zal hebben.

Door een goede samenwerking tussen huisarts en specialist zal voor alle partijen de situatie verbeteren. De huisartsenopleiding in Maastricht heeft oogheelkunde als aandachtsgebied. Er is een project gestart om de haalbaarheid van de bovenbeschreven opzet te toetsen. Met 
veel enthousiasme is men in deze gestart en wij hebben direct de volledige medewerking gegeven om van ons uit dit hele project te begeleiden. Het is namelijk van essentieel belang, dat dergelijke initiatieven door beide discipline's worden gedragen en ondersteund. Laat een van beide het afweten dan is het tot mislukken gedoemd. Verder zullen de beide beroepsgroepen met elkaar tot overeenstemming moeten komen en gezamenlijk deze ontwikkeling dragen. $\mathrm{Er}$ is echter nog een derde partner in het spel en dat is de overheid c.q. de ziektekostenverzekeraars. De tariefstructuur is op deze situatie niet geënt en zal dan ook moeten worden aangepast. Het behoort tot de taak van de beide beroepsgroepen om samen met de overheid tot een evenwichtig pakket te komen. Ik heb er het volste vertrouwen in dat dit op deze manier tot een succes wordt, uiteindelijk tot tevredenheid van alle partijen. Op de eerste plaats de patiënt, die een optimale oogheelkundige zorg krijgt, de beroepsbeoefenaren, die hun arbeidsvreugde zien stijgen zonder onder het bestaansminimum te moeten leven en tenslotte de overheid, die een efficiënte en op kwaliteit toegesneden zorg krijgt voor zijn mensen, die misschien niet het allergoedkoopste is maar zeker kwaliteit geeft voor zijn geld.

Aan het einde gekomen van mijn afscheids-

rede wil ik nog kort bij twee zaken stilstaan. Allereerst het functioneren van de afdeling c.q. vakgroep oogheelkunde en tenslotte is het mij een behoefte enkele mensen, die voor mij van bijzondere betekenis zijn geweest, te danken.

\section{In 1977 ben ik als hoogleraar Oogheel-} kunde benoemd bij de Rijksuniversiteit Limburg. Dat was de start van de academisering van de oogheelkunde in het toenmalige St. Annadal Ziekenhuis. Als eenmanspraktijk gestart is toen een begin gemaakt met de opbouw van een universitaire afdeling. Tot de taken van een dergelijke afdeling behoren Gezondheidszorg, Onderwijs, en Onderzoek. Gezondheidszorg was al aanwezig, alleen moest het niveau worden opgevijzeld, onderwijs en onderzoek moesten van de grond af worden opgebouwd. Een van de 
grootste problemen in de beginjaren was de onmogelijkheid oogartsen aan te trekken. Met de beschikbare mankracht was het al moeilijk de gezondheidszorg goed te laten verlopen. En met veel kunst en vliegwerk werd ook nog aan de onderwijs verplichting voldaan, zodat weinig ruimte overbleef voor onderzoek. Bovendien is het onderzoek binnen onze universiteit tot bepaalde thema's beperkt. En het was voor ons moeilijk om binnen deze thematiek onderzoek te starten, reden waarom wij uiteindelijk zijn uitgeweken naar het IOI in Amsterdam, waar wij wel de gelegenheid hebben gekregen basaal onderzoek te starten, hetgeen dan ook al meerdere resultaten heeft opgeleverd. Het is namelijk erg belangrijk, dat door de klinische groepen en met name de artsassistenten, basaal wetenschappelijk onderzoek wordt verricht. Dit zal moeten gebeuren voor men met de opleiding begint. Voor de wetenschappelijke vorming van de klinici is dat bijzonder belangrijk. In het ziekenhuis wordt gesproken van de afdeling, bij de faculteit zijn we bekend als de vakgroep. De afdeling heeft als voornaamste taak gezondheidszorg, bij de vakgroep ligt het accent op onderwijs en onderzoek. In wezen zijn afdeling en vakgroep identiek. Maar de belangen van het Academisch Ziekenhuis en de Faculteit lopen niet altijd parallel. Dat moet tot spanningen leiden binnen een afdeling/vakgroep. Het ziekenhuis heeft niet altijd veel oog voor onderwijs en vooral basaal onderzoek, de faculteit laat de gezondheiszorg vaak buiten beschouwing. Ik denk dat het goed zou zijn als er een betere afstelling zou komen tussen beide. Het begrip voor elkaar is tussen beide vaak ver te zoeken. Ik hoop dat mijn opvolger de mogelijkheid wordt gegeven zijn vleugels verder uit te slaan, zodanig dat alle aspecten ten volle kunnen worden uitgebouwd.

Tenslotte wil ik nog enkele woorden wijden aan die mensen, die van bijzondere betekenis zijn geweest in mijn professionele leven. Allereerst zijn dat mijn ouders. $\mathrm{Zij}$ hebben mij het leefmilieu gegeven, waarbinnen ik me heb kunnen ontplooien. Ook mijn oogheelkundige vader wil ik op deze plaats memoreren. Prof. van den Heuvel heeft als mijn opleider een dui- 
delijke stempel gedrukt op mijn oogheelkundig leven. Hij heeft ons doordrongen van het feit, dat we geen orgaan behandelen, maar een mens. Veel ben ik aan hem verschuldigd en het is jammer, dat hij niet tegenwoordig kan zijn bij mijn afscheid als hoogleraar Oogheelkunde. In ieder geval neemt hij in de harten van zijn leerlingen een bijzondere plaats in. Het is me dan ook een echte behoefte om mijn genegenheid langs deze weg te tonen. Er zijn vele mensen in mijn leven, die een grote rol hebben gespeeld. Ik kan zeker niet iedereen noemen. Ten onrechte zou ik dan sommigen misschien vergeten of de lijst wordt zo lang dat er geen einde aan komt. Twee categorieën wil ik nog met name noemen. Dat zijn de medewerkers van de afdeling oogheelkunde en mijn naaste familie. Zonder de hulp van alle medewerkers zou het voor mij onmogelijk zijn geweest ook maar iets tot stand te brengen. Als er al iets van de grond is gebracht dan is het voor het grootste deel aan jullie te danken. Het is soms best moeilijk geweest om het hoofd boven water te houden, maar iedereen heeft zich altijd voor meer dan 100\% ingezet om het onmogelijke mogelijk te maken. Ik ben de stafleden en alle andere medewerkers uitermate dankbaar. Een speciaal woord wil ik nog wijden aan de arts-assistenten. Ik heb er nooit een geheim van gemaakt, dat mijn verhouding tot de arts-assistenten er een is als van een vader tot zijn kinderen. Ik heb me altijd nauw betrokken gevoeld met jullie wel en wee. Dat wil niet zeggen, dat ik alles wat jullie ondernemen kan onderschrijven, maar als ik kritiek heb op jullie handelen dan is dat uit een genegenheid die op de eerste plaats staat. Tenslotte kom ik aan de laatsten, die ik zou willen memoreren, Jet en de kinderen. Ik heb het onvoorstelbare geluk gehad een harmonieus gezinsleven te mogen ervaren. Binnen ons gezin is mij de rust gegund mij ongestoord aan mijn vak te kunnen wijden. Het is de verdienste van mijn vrouw, die het klimaat heeft geschapen, waarbinnen dit allemaal kon gedijen. Zonder deze voorwaarde is het niet mogelijk behoorlijke prestaties te leveren. De kinderen dank ik voor het begrip wat ze altijd hebben opgebracht als bepaalde activiteiten niet konden doorgaan, omdat pa zo nodig weer iets oog- 
heelkundigs moest doen. Tenslotte nog een persoonlijk woord aan jou, Jet. Lieve Jet, jij bent nu al meer dan 34 jaar mijn steun en toeverlaat geweest. We hebben zeer veel lief en een beetje leed met elkaar gedeeld. Wat ik heb bereikt is voor het allergrootste deel aan jou te danken. Jouw relativerende kijk op het leven, jouw eerlijkheid en bovenal jouw liefde voor ons is van onschatbare waarde geweest bij alles wat ik mogelijk heb bereikt. Eigenlijk zou jij op mijn plaats moeten staan. Jet ik dank je uit de grond van mijn hart en ik zou dit tot uiting willen brengen met bloemen, die je nu zullen worden overhandigd namens mij en de kinderen door onze dochter Marie-Thérèse.

ik heb gezegd 
Handbuch der Gesamten Augenbeilkunde Band XII Geschichte der Augenheilkunde J.Hirschberg 1899

Augenärztlichen Operationen

Dr. Wilhelm Czermak 1893

Iconographie Ophthalmologique

J. Sichel Paris 1852

Handbuch der gesamten Augenheilkunde

Band XIII Geschichte der Augenheilkunde

J. Hirschberg 1899

Lensimplantation

30 years of progress

P. Leonard, J. Rommel 1982 